\title{
Rapid diagnosis of pulmonary TB by BAL enzyme-linked immunospot assay in an
} immunocompromised host

\author{
A. Strassburg*, C. Jafari*, M. Ernst ${ }^{*}$, W. Lotz ${ }^{\#}$ and C. Lange*
}

ABSTRACT: Immunocompromised patients with acid-fast bacilli (AFB) smear-negative active pulmonary tuberculosis (PTB) often present with nonspecific clinical symptoms and findings. T-cell interferon- $\gamma$ release assays (TIGRA) performed on whole blood (using ELISA) or peripheral blood mononuclear cells (using enzyme-linked immunospot assay (ELISPOT)) are more sensitive for the diagnosis of Mycobacterium tuberculosis (MTB) infection than the tuberculin skin test (TST), but cannot distinguish active from latent MTB infection.

The present authors report a 38-yr-old female presenting with a 3-week history of malaise, dyspnoea, fevers and coughing, who had received immunosuppressive therapies over 8 months for mixed connective tissue disease. Chest radiograph and thoracic computed tomography showed ground glass opacities in both lower lobes. The TST-induration was $\mathbf{0 ~ m m}$ and AFBs or MTB nucleic acid was not detected on sputum and bronchial secretions. However, TIGRAs performed on peripheral blood cells were reactive. A high frequency of MTB-specific T-cells compatible with the immunodiagnosis of active PTB was detected among bronchoalveolar lavage cells using ELISPOT. Antituberculous therapy was initiated 18 days before MTB was discovered on sputum cultures.

Detection of Mycobacterium tuberculosis-specific T-cells in the bronchoalveolar lavage using enzyme-linked immunospot assay is a promising tool for the diagnosis of active pulmonary tuberculosis in immunocompromised patients with negative acid-fast bacilli smears.

KEYWORDS: Bronchoalveolar lavage, diagnosis, enzyme-linked immunospot, immunosuppression, T-cell interferon- $\gamma$ release assay, tuberculosis

$\mathbf{R}$ eactivation of latent Mycobacterium tuberculosis (MTB) infection (LTBI) is associated with significant morbidity and mortality, especially in immunocompromised individuals [1, 2]. However, the diagnosis of active pulmonary tuberculosis (pTB) can be challenging in the immunocompromised host because clinical appearance and findings, such as typical radiological patterns, may be absent [3]. Additionally, in $\sim 65 \%$ of immunocompromised patients with active $\mathrm{pTB}$, the result of the tuberculin skin test (TST) is falsely negative [4]. When detection of acid-fast bacilli (AFB) in sputum or bronchial secretions is not possible and MTB DNA cannot be detected by nucleic acid amplification, the diagnosis of pTB by identification of MTB in liquid or solid culture media is delayed for several weeks [5]. In $\sim 20 \%$ of patients with pTB, MTB cannot be recovered from cultures of bronchial secretions at all [6].

Recently, enumeration of MTB-specific T-cells from the bronchoalveolar lavage (BAL) was shown to be a promising tool for the rapid detection of patients with smear-negative pTB [7]. However, it was unclear whether the immunodiagnosis of active pTB could be also established by BAL enzyme-linked immunospot assay (ELISPOT) in immunocompromised hosts.

\section{CASE REPORT}

In January 2007, a 38-yr-old nonsmoking female presented to an outside hospital, with a 3-week history of severe malaise, progressive dyspnoea, recurrent fevers and a dry cough. Approximately 15 yrs ago, the patient fled her home country, Sri Lanka, and, following an odyssey, she was then
AFFILIATIONS

${ }^{*}$ Divisions of *Clinical Infectious Diseases and

"Immune Cell-Analytics, Medical Clinic, Research Center Borstel, Borstel, Germany.

CORRESPONDENCE

C. Lange

Div. of Clinical Infectious Diseases Medical Clinic

Research Center Borstel

Parkallee 35

D-23845 Borstel

Germany

Fax: 494537188313

E-mail: clange@fz-borstel.de

Received:

July 062007

Accepted after revision:

October 022007

STATEMENT OF INTEREST

A statement of interest for $\mathrm{C}$. Lange can be found at www.erj.ersjournals. $\mathrm{com} / \mathrm{misc} / \mathrm{statements.shtml}$

European Respiratory Journal Print ISSN 0903-1936 Online ISSN 1399-3003 
granted asylum in Germany. The patient denied a history of TB or known TB contacts.

However, 18 months prior to admission, she gradually developed myalgias of the upper arms radiating into both hands, accompanied by recurrent swelling of the fingers, pain in the upper spine, morning stiffness and symmetric arthralgias of the knees. The diagnosis of seropositive rheumatoid arthritis was performed after finding the rheumatic factor in her serum, and treatment with systemic corticosteroids $(20 \mathrm{mg}$ of prednisolone equivalent) was initiated with good clinical response. Unfortunately, 8 months prior to admission, after tapering the corticosteroids to a dose of $5 \mathrm{mg} \cdot \mathrm{day}^{-1}$, the symptoms reappeared and weekly treatment with $15 \mathrm{mg}$ of the folate antimetabolite methotrexate was started in order to spare corticosteroids.

The physical examination on admission revealed oedema of the hands, feet, lips and cheeks. The patient described sudden onset of cold fingers and toes in association with sharply demarcated colour changes of the skin, which was diagnosed as Raynaud's phenomenon. Increasing hyposensitivity of the finger and toe tips was also described. Upon passive movement, the patient complained of painful ankle, hand and knee joints. There were painful purple nodules on both tibiae and calves.

The peripheral blood count showed a haemoglobin level of $11.5 \mathrm{~g} \cdot \mathrm{dL}^{-1}$, a white blood cell count of $6.8 \times 10^{9}$ cells $\cdot \mathrm{L}^{-1}$ and a platelet count of $275 \times 10^{9}$ cells $\cdot \mathrm{L}^{-1}$. The levels of creatinine kinase $\left(632 \mathrm{U} \cdot \mathrm{L}^{-1}\right), \gamma$-glutamyl transferase $\left(96 \mathrm{U} \cdot \mathrm{L}^{-1}\right)$, alkaline phosphatase $\left(119 \mathrm{U} \cdot \mathrm{L}^{-1}\right)$, lactate dehydrogenase $\left(619 \mathrm{U} \cdot \mathrm{L}^{-1}\right)$ and C-reactive protein $\left(89 \mathrm{mg} \cdot \mathrm{L}^{-1}\right)$ were elevated. The erythrocyte sediment rate was $80 \mathrm{~mm}$ within the first hour.

Screening for HIV, hepatitis B and C, Epstein-Barr virus, and Borrelia burgdorferi was negative. An anti-nuclear antibody with a titre of 1:20,480 (speckled-type) was found. Antibodies against recombinant $\mathrm{A}, \mathrm{C}$ and $68 \mathrm{kD}$-ribonucleoprotein were detected. The diagnosis of mixed connective tissue disease (MCTD) was performed and treatment with prednisolone at a dosage of $20 \mathrm{mg}$ was reinitiated without continuing methotrexate.

Despite these interventions, the patient suffered from ongoing fever up to $39^{\circ} \mathrm{C}$. Several blood cultures remained sterile and, despite extensive radiological imaging, no focus for her febrile illness could be found. A T-cell interferon (IFN)- $\gamma$ release assay (TIGRA; QuantiFERON-TB Gold in-tube test ${ }^{\text {TM}}$; Cellestis Ltd, Carnegie, Australia) on the peripheral blood was strongly positive with $3.12 \mathrm{IU} \cdot \mathrm{mL}^{-1}$ (cut-off value $<0.35 \mathrm{IU} \cdot \mathrm{mL}^{-1}$ ), suggesting latent infection with MTB, past TB or active TB. As the antigens used for the TIGRA, early antigenic target (ESAT)-6 and culture filtrate protein (CFP)-10 may cross-react with antigens form Mycobacterium leprae [8, 9], a skin biopsy from the lesions on the lower leg was performed, which revealed a diagnosis of erythema nodosum. PCR for Mycobacterium leprae from the lesions was negative.

After 4 weeks in hospital, the patient was transferred to the present authors' clinic (Medical Clinic, Research Center Borstel, Borstel, Germany) for further diagnosis. Following admission, a high-resolution computed tomography scan of the thorax showed no pleural effusions, adenopathy, cavitations, consolidations or tree-in-bud phenomena. Symmetrical ground glass opacity predominantly in the lower lung segments, as in nonspecific interstitial pneumonitis, compatible with the diagnosis of MCTD, was demonstrated (fig. 1) [10, 11].

Tuberculin PPD RT 23 SSI (2 TU/0.1 mL solution for injection; Statens Serum Institute, Copenhagen, Denmark) revealed $0 \mathrm{~mm}$ of induration after 48 and $72 \mathrm{~h}$. However, with another MTBspecific TIGRA, the T-SPOT.TB assay (Oxford Immunotec, Abingdon, UK), 59 and 31 spot-forming cells (SFCs) per 250,000 peripheral blood mononuclear cells (PBMCs) were enumerated in response to ESAT-6 and CFP-10 in blood samples (cut-off value >5 SFCs/250,000 PBMCs; fig. 2 and table 1). Treatment with isoniazid $5 \mathrm{mg} \cdot \mathrm{kg}^{-1}$ of bodyweight was initiated for the diagnosis of LTBI.

AFBs were not seen on three separate morning sputa. MTB DNA could not be detected in sputum of the patient by MTBspecific nucleic acid amplification technique (BDProbeTec ${ }^{\mathrm{TM}}$ ET assay; Becton Dickinson, Sparks, MD, USA). Subsequently, bronchoscopy with BAL and transbronchial biopsies was performed. The BAL differential count revealed a lymphocytic alveolitis with $77 \%$ alveolar macrophages, 18\% lymphocytes, $4 \%$ neutrophils and $0.6 \%$ eosinophils. Neither AFBs nor MTB DNA could be detected on the BAL. Histopathological examination of the biopsies showed lymphocyte and neutrophil cell infiltrates without demonstration of granulomas.

MTB-specific ELISPOT (Oxford Immunotec) was performed on BAL mononuclear cells (BALMCs) as previously described [7], to discriminate active TB from LTBI. In unstimulated controls, 117 SFCs /250,000 BALMCs were found. However, numbers of ESAT-6 and CFP-10 SFCs both exceeded 400/250,000, demonstrating pre-stimulated lymphocytes and recruitment of MTB antigen-specific T-cells to the lung, strongly suggestive of active pTB (fig. 2 and table 1).

Upon receipt of these results, treatment with rifampin, ethambuthol and pyrazinamid was added for quadruple



FIGURE 1. Representative high-resolution computed tomography scan of the thorax demonstrating symmetrical ground glass opacity predominantly in the lower lung segments, as in nonspecific interstitial pneumonitis, compatible with the diagnosis of mixed connective tissue disease. Neither pleural effusions, adenopathy, cavitations, consolidations nor tree-in-bud phenomena could be found. 



FIGURE 2. Mycobacterium tuberculosis-specific enzyme-linked immunospot assay for the diagnosis of pulmonary tuberculosis. Microtitre wells are shown following incubation with 250,000 peripheral blood mononuclear cells (a, c, e and g) or 250,000 bronchoalveolar mononuclear cells each (b, d, f and h) and either unstimulated (negative control; a and b) or stimulated with phytohaemaglutinine (positive control; c and d), early secretory antigenic target-6 (e and f) or culture filtrate protein-10 ( $\mathrm{g}$ and $\mathrm{h}$ ).

antituberculous therapy. After 18 days, MTB was discovered on a sputum culture from the patient.

\section{DISCUSSION}

TIGRAs (ELISPOT and T-SPOT.TB; Oxford Immunotec. ELISA; QuantiFERON-TB Gold in-tube test ${ }^{\text {TM}}$; Cellestis Ltd) based on MTB-RD1 peptides ESAT-6 and CFP-10 (the QuantiFERON-TB Gold in-tube test ${ }^{\mathrm{TM}}$ also has TB.7.7 antigen) have a sensitivity of $83-97 \%[12,13]$ and a specificity of $92-$ $100 \%[13,14]$, and therefore provide a much more reliable means of detecting MTB-specific immune response on peripheral blood cells than the TST (sensitivity: 55-74\%; specificity: $56-98 \%$ [13]). In contrast to the TST, TIGRAs are not influenced by prior bacille Calmette-Guerin vaccination and have lower cross-reactivity to nontuberculous mycobacteria [15-18]. Several reports confirm the diagnostic superiority in immunocompromised hosts of T-cell-based blood tests over the TST [19-23]. However, like the TST, TIGRAs do not allow a distinction between active TB and LTBI when performed on blood.

In TB, antigen-specific T-cells clonally expand and are recruited to the site of infection [24-26]. The IFN- $\gamma$ release measured by MTB-specific ELISPOT can be directly related to the number of antigen-specific mononuclear cells in biological specimens. Thus, it was recently shown that MTB-specific IFN$\gamma$-secreting T-cells are concentrated among mononuclear cells in the BAL, in pleural effusion, ascites and cerebrospinal fluid of patients with smear-negative pulmonary or extrapulmonary tuberculosis [7, 27-29]. Enumerating MTB-specific T-cells among cells from the pleural effusion by ELISPOT also proved to be efficient for the diagnosis of active pleural TB in an immunocompromised patient [30].

In a prospective pilot study, MTB-specific ELISPOT was evaluated for the diagnosis of active pTB in patients with suspected $\mathrm{pTB}$ in whom AFBs were not detectable from three consecutive sputum smears [7]. ESAT-6 and CFP-10 peptidespecific responses were only detectable in BALMCs in the 12 patients with active PTB in the study by JAFARI et al. [7], while these responses were absent in 25 patients with LTBI or a

\begin{tabular}{|c|c|c|c|c|}
\hline \multirow[t]{3}{*}{ TABLE 1} & \multicolumn{4}{|c|}{$\begin{array}{l}\text { Net numbers of spot-forming cells (SFCs) and } \\
\text { interpretation of Mycobacterium tuberculosis- } \\
\text { specific enzyme-linked immunospot assay } \\
\text { reactivity }\end{array}$} \\
\hline & \multicolumn{2}{|c|}{ SFCs } & \multicolumn{2}{|c|}{ Reactivity } \\
\hline & PBMC & BALMC & PBMC & BALMC \\
\hline Unstimulated & 2 & 117 & - & + \\
\hline PHA & $>250$ & $>250$ & + & + \\
\hline ESAT- 6 & $43(45-2)$ & $>250(>400-117)$ & + & + \\
\hline CFP-10 & $74(76-2)$ & $>250(>400-117)$ & + & + \\
\hline
\end{tabular}

Data are presented as SFCs or SFCs (number of total SFCs - number of SFCs in the negative control well). PBMC: peripheral blood mononuclear cells; BALMC: bronchoalveolar mononuclear cells; PHA: phytohaemaglutinine; ESAT early secretory antigenic target; CFP: culture filtrate protein. For PBMCs, $>5$ SFCs and at least twice the number of SFCs than in the negative control well are recommended by the manufacturer as a positive test response. For BALMCs, no official recommendations for cut-off values exist as yet. +: positive test response; -: negative test response.

history of TB but without current reactivation or pulmonary infiltrates of other origin.

In the present report the first evidence is provided that enumerating of Mycobacterium tuberculosis-specific T-cells by enzyme-linked immunospot assay among bronchoalveolar lavage mononuclear cells may be a useful diagnostic tool for the rapid detection of active tuberculosis in immunocompromised individuals. Large prospective multicentre trials, similar to the one conducted currently by the Tuberculosis Network European Trials group, are needed to validate the clinical utility of the Mycobacterium tuberculosis-specific bronchoalveolar lavage enzyme-linked immunospot assay and to compare its diagnostic performance with a Mycobacterium tuberculosisspecific nucleic acid amplification testing for the rapid diagnosis of pulmonary tuberculosis in patients with smearnegative acid-fast bacilli sputum findings.

\section{REFERENCES}

1 Oursler KK, Moore RD, Bishai WR, Harrington SM, Pope DS, Chaisson RE. Survival of patients with pulmonary tuberculosis: clinical and molecular epidemiologic factors. Clin Infect Dis 2002; 34: 752-759.

2 Rao VK, Iademarco EP, Fraser VJ, Kollef MH. The impact of comorbidity on mortality following in-hospital diagnosis of tuberculosis. Chest 1998; 114: 1244-1252.

3 Castro KG. Tuberculosis as an opportunistic disease in persons infected with human immunodeficiency virus. Clin Infect Dis 1995; 21: Suppl. 1, S66-S71.

4 Piana F, Codecasa LR, Cavallerio P, et al. Use of a T-cellbased test for detection of tuberculosis infection among immunocompromised patients. Eur Respir J 2006; 28: 31-34.

5 Hanna BA, Ebrahimzadeh A, Elliott LB, et al. Multicenter evaluation of the BACTEC MGIT 960 system for recovery of mycobacteria. J Clin Microbiol 1999; 37: 748-752. 
6 Altmann D, Brodhun B, Haas W. Report on the epidemiology of tuberculosis for 2005. Berlin, Robert Koch Institute, 2006. www.rki.de/cln_048/nn_197444/DE/Content/InfAZ/ T/Tuberkulose/WeltTBTag2007/TB2005.html?_nnn=true Date updated: March 22, 2007.

7 Jafari C, Ernst M, Kalsdorf B, et al. Rapid diagnosis of smear-negative tuberculosis by bronchoalveolar lavage enzyme-linked immunospot. Am J Respir Crit Care Med 2006; 174: 1048-1054.

8 Geluk A, van Meijgaarden KE, Franken KL, et al. Immunological crossreactivity of the Mycobacterium leprae CFP-10 with its homologue in Mycobacterium tuberculosis. Scand J Immunol 2004; 59: 66-70.

9 Gey Van Pittius NC, Gamieldien J, Hide W, Brown GD, Siezen RJ, Beyers AD. The ESAT-6 gene cluster of Mycobacterium tuberculosis and other high G+C Grampositive bacteria. Genome Biol 2001; 2: 1-18.

10 Saito Y, Terada M, Takada T, et al. Pulmonary involvement in mixed connective tissue disease: comparison with other collagen vascular diseases using high resolution CT. J Comput Assist Tomogr 2002; 26: 349-357.

11 Bodolay E, Szekanecz Z, Dévényi $\mathrm{K}$, et al. Evaluation of interstitial lung disease in mixed connective tissue disease (MCTD). Rheumatology (Oxford) 2005; 44: 656-661.

12 Richeldi L. An update on the diagnosis of tuberculosis infection. Am J Respir Crit Care Med 2006; 174: 736-742.

13 Menzies D, Pai M, Comstock G. Meta-analysis: new tests for the diagnosis of latent tuberculosis infection: areas of uncertainty and recommendations for research. Ann Intern Med 2007; 146: 340-354.

14 Yew WW, Leung CC. Update in tuberculosis 2006. Am J Respir Crit Care Med 2007; 175: 541-546.

15 Brock I, Weldingh K, Lillebaek T, Follmann F, Andersen P. Comparison of tuberculin skin test and new specific blood test in tuberculosis contacts. Am J Respir Crit Care Med 2004; 170: 65-69.

16 Diel R, Ernst M, Döscher G, et al. Avoiding the effect of BCG vaccination in detecting Mycobacterium tuberculosis infection with a blood test. Eur Respir J 2006; 28: 16-23.

17 Zellweger JP, Zellweger A, Ansermet S, de Senarclens B, Wrighton-Smith P. Contact tracing using a new T-cellbased test: better correlation with tuberculosis exposure than the tuberculin skin test. Int J Tuberc Lung Dis 2005; 9: 1242-1247.
18 Shams H, Weis SE, Klucar P, et al. Enzyme-linked immunospot and tuberculin skin testing to detect latent tuberculosis infection. Am J Respir Crit Care Med 2005; 172: 1161-1168.

19 Gooding S, Chowdhury O, Hinks T, et al. Impact of a T cellbased blood test for tuberculosis infection on clinical decision-making in routine practice. J Infect 2007; 54: e169-e174.

20 Ravn P, Munk ME, Andersen AB, et al. Reactivation of tuberculosis during immunosuppressive treatment in a patient with a positive QuantiFERON-RD1 test. Scand J Infect Dis 2004; 36: 499-501.

21 Richeldi L, Ewer K, Losi M, et al. Early diagnosis of subclinical multidrug-resistant tuberculosis. Ann Intern Med 2004; 140: 709-713.

22 Richeldi L, Luppi M, Losi M, et al. Diagnosis of occult tuberculosis in hematological malignancy by enumeration of antigen-specific T cells. Leukemia 2006; 20: 379-381.

23 Chapman AL, Munkanta M, Wilkinson KA, et al. Rapid detection of active and latent tuberculosis infection in HIVpositive individuals by enumeration of Mycobacterium tuberculosis-specific T cells. AIDS 2002; 16: 2285-2293.

24 Barnes PF, Lu S, Abrams JS, Wang E, Yamamura M, Modlin RL. Cytokine production at the site of disease in human tuberculosis. Infect Immun 1993; 61: 3482-3489.

25 Flynn JL, Chan J. Immunology of tuberculosis. Annu Rev Immunol 2001; 19: 93-129.

26 Jafari C, Ernst M, Strassburg A, et al. Local immunodiagnosis of pulmonary tuberculosis by enzyme-linked immunospot. Eur Respir J 2008; 31: 261-265.

27 Wilkinson KA, Wilkinson RJ, Pathan A, et al. Ex vivo characterization of early secretory antigenic target 6specific $\mathrm{T}$ cells at sites of active disease in pleural tuberculosis. Clin Infect Dis 2005; 40: 184-187.

28 Losi M, Bossink A, Codecasa L, et al. Use of a T-cell interferon- $\gamma$ release assay for the diagnosis of tuberculous pleurisy. Eur Respir J 2007; 30: 1173-1179.

29 Kösters K, Nau R, Bossink A, et al. Rapid diagnosis of CNS tuberculosis by a T-cell interferon- $\gamma$ release assay on cerebrospinal fluid mononuclear cells. Infection 2008; [Epub ahead of print PMID: 18193383].

30 Lange C, Hellmich B, Ernst M, Ehlers S. Rapid immunodiagnosis of tuberculosis in a woman receiving anti-TNF therapy. Nat Clin Pract Rheumatol 2007; 3: 528-534. 